\title{
Gastric Choriocarcinoma
}

National Cancer Institute

\section{Source}

National Cancer Institute. Gastric Choriocarcinoma. NCI Thesaurus. Code C95749.

A malignant germ cell tumor that arises from the stomach. It is characterized by the presence of syncytiotrophoblast and cytotrophoblast cellular components. It is often associated with lymph node and hematogenous metastases. 